\title{
Correction to: Determinants of exclusive breastfeeding in infants of six months and below in Malawi: a cross sectional study
}

\author{
Yusuf M. Salim ${ }^{1 *}$ and William Stones ${ }^{2}$
}

\section{Correction to: BMC Pregnancy Childbirth 20, 472 (2020) \\ https://doi.org/10.1186/s12884-020-03160-y}

Following publication of the original article [1], we have been notified that under Discussion section on page 6 of 8, paragraph 3, there is an error. In this Correction, incorrect and correct versions are shown.

Incorrect: "In Malawi, HIV prevalence is low in the northern region (where Tumbukas and Ngonis are largely found) than southern and central [7]. This has been attested by MPHIA Survey of 2015-2016 which reported that overall prevalence of HIV in northern region was $7.4 \%$, central region $22.5 \%$ and in southern region $49 \%$ [21]."

Correct: "In Malawi, HIV prevalence varies regionally. Northern region (where Tumbuka and Ngoni communities are largely found) records a prevalence of $7.4 \%$ with $4.9 \%-6.1 \%$ in rural zones of the central region, rural zones of the southern region at $15.3-16.0 \%$ and as high as $17.7 \%$ in Blantyre, the main urban centre in the south [21]."

\footnotetext{
Author details

${ }^{1}$ Karonga District Hospital, Private Bag 1, Karonga, Malawi. ${ }^{2}$ College of Medicine, Private Bag 360, Blantyre, Malawi.
}

Published online: 11 September 2020

\section{Reference}

1. Salim YM, Stones W. Determinants of exclusive breastfeeding in infants of

six months and below in Malawi: a cross sectional study. BMC Pregnancy Childbirth. 2020;20:472. https://doi.org/10.1186/s12884-020-03160-y.

The original article can be found online at https://doi.org/10.1186/s12884020-03160-y.

* Correspondence: ayuyayusuf@gmail.com

${ }^{1}$ Karonga District Hospital, Private Bag 1, Karonga, Malawi

Full list of author information is available at the end of the article

(c) The Author(s). 2020 Open Access This article is licensed under a Creative Commons Attribution 4.0 International License, which permits use, sharing, adaptation, distribution and reproduction in any medium or format, as long as you give appropriate credit to the original author(s) and the source, provide a link to the Creative Commons licence, and indicate if changes were made. The images or other third party material in this article are included in the article's Creative Commons licence, unless indicated otherwise in a credit line to the material. If material is not included in the article's Creative Commons licence and your intended use is not permitted by statutory regulation or exceeds the permitted use, you will need to obtain permission directly from the copyright holder. To view a copy of this licence, visit http://creativecommons.org/licenses/by/4.0/. The Creative Commons Public Domain Dedication waiver (http://creativecommons.org/publicdomain/zero/1.0/) applies to the data made available in this article, unless otherwise stated in a credit line to the data. 